\title{
Evaluation of the toxicity of cyanogens in a commonly consumed Nigeria legume pigeon pea (Cajanus cajan) seed and its biochemical effects in rabbits
}

\author{
L. A. NWAOGU* and A. A. EMEJULU \\ Department of Biochemistry, Federal University of Technology, \\ P.M.B 1526, Owerri, Nigeria. \\ *Corresponding author, E-mail: nwogulinus@yahoo.com.
}

\begin{abstract}
The effect of a commonly consumed Nigeria legume pigeon pea (Cajanus cajan) seeds with high cyanogen concentration on some important biochemical parameters and haemoglobin concentration in new Zealand rabbits was investigated over a period of 72 hours. Quantitative analysis of the legume seed revealed that it has in $\mathrm{mg} / 100 \mathrm{~g}$ dry weight $39.3 \pm 1.30$ cyanogenic glycosides, $11.57 \pm 1.20$ phytate, $28.58 \pm 1.02$ oxalate and $3.80 \pm 0.01 \mathrm{Tiu} / 100 \mathrm{~g}$ dry weight typsin inhibitor respectively. Analysis of the serum and urine samples from test and control rabbits indicated that there was no significant difference $(p \leq 0.05)$ in the concentrations of total protein, bilirubin, inorganic phosphate and creatinine. There was a slight decrease in the activities of alkaline phosphatase. However, the activities of serum transaminases: alanine amino transferase (ALT), aspartate amino transferase (AST) as well as cyanide concentration increased significantly $(\mathrm{P} \leq \pm 0.05)$. Cyanide concentration in the serum increased from 5 to $27 \mathrm{mg} / \mathrm{l}$ and that in the urine from 3.5 to $26 \mathrm{mg} / \mathrm{l}$ in the rabbits fed with commercial feed when compared to those fed with Cajanus cajan formulated feed. The study revealed that consumption of Cajanus cajan seed made pulses occasionally would not result to cyanide toxicity.
\end{abstract}

(C) 2010 International Formulae Group. All rights reserved.

Keywords: Toxicity, cyanogens, antinutrient composition, cajanus cajan, rabbits.

\section{INTRODUCTION}

Plants and plant parts constitute the major source of food for man due to their availability and low cost (Obizoba, 1998). Most people in developing countries derive their dietary protein supplies from legumes and cereals, since the consumption of animal protein may be limited as result of economic, social, cultural and religious factors (Obizoba, 1991).
Pigeon pea (Cajanus cajan) seed is commonly cultivated in Nigeria and other tropical countries (Elegbede, 1998). In Nigeria, it is more popular in the northern and western States. In the eastern states, it is eaten in Enugu State but is more popular among Nsukka people. It is commonly called "Ogbugba" or "Fiofio" (Obizoba, 1998). Pigeon pea is one of the under utilized legumes, probably because of lack of 
knowledge of its nutritional value (Elegbede, 1998).

Cajanus cajan is a woody perennial crop, living up to 4 years. It bears well in the first year, profusely in the second and third year, but progressively less thereafter. It has a deep tap root and a massive fibrous lateral roots with spherical nodules which are sometimes lobed. The pods are straight and flattered, slightly hairy and usually $4.5 \mathrm{~cm}$ long. There are variation in the seeds which are usually spherical, brownish, specked with milky white coloured sports (Allen and Allen, 1981). Legumes are known to contain antinutritional factors (ANF), which reduce their protein digestibility and nutritional value (Onigbinde and Akinyele, 1983). One potentially toxic constituent of legumes are the cyanogenic glycosides. Evidence for the cyanogen contents of some Nigerian legumes have been provided (Okolie and Ugochukwu, 1988; Osagie, 1998). Several reports exist on the acute and chronic toxicity of cyanogenic glycosides of plants towards man and animals (Ekpeche, 1973; Osagie, 1998). This emphasizes the fact that cyanide is widely distributed in nature and that some amount of cyanide is consumed as part of our daily diet from root crops, legumes, cereals, etc. Cyanide is a constituted of the blood usually at low concentration less than $12 \mu$ mole (Osagie, 1998). Aremu (1989) estimated that the per capita daily intake of hydrocyanate in Nigeria was $8 \mathrm{mg}$, almost $90 \%$ of which is from garri alone. The consumption of foods containing cyanogens would result in acute or chronic toxicity. Osagie (1998) reported that Cajanus cajan usually consumed in some parts of Nigeria as pulses contain high concentration of cyanogens. Investigation of the cyanogenic glycosides and the biochemical effects of this legume on animals is desirable in view of the increasing consumption of this legume presently as a source of dietary protein. This forms the aim of this study.

\section{MATERIALS AND METHODS \\ Collection and treatment of Cajanus cajan seeds}

The edible seeds of Cajanus cajan brownish-red variety used for this study were purchased from Ogbete market in Enugu State. The seeds were identified by Mr. Obi Ogbonnaya at the National Root Crop Research Institute Umudike, Umuahia, Abia State, Nigeria. The seeds were boiled, dried and milled in a hammar mill (70 mash screen) to fine flour. The treatment feed was prepared by mixing thoroughly $90 \%$ of the ground Cajanus cajan flour with $10 \%$ commercial feed bought from Eke-Ukwu Owerri Market. This was then kept in a clean dry plastic container and stored in a cool dry place until required for use.

\section{Animals and treatment}

Ten male New Zealand rabbits weighing between 950 to $1000 \mathrm{~g}$ bought from the Research farm of Michael Okpara University of Agriculture Umudike Umuahia, Nigeria, were used for this study. The animals were grouped into two of five rabbits each. Group 1 served as test, while Group 2 served as the control. The animals in each group were housed in stainless steel cages and acclimatized under standard environmental conditions $\left(27{ }^{\circ} \mathrm{C}\right.$ and $12 \mathrm{hr}$ light/dark cycle) with access to commercial feed and water $a d$ libtum for 21 days and then allowed to starve for 24 hours so as to eliminate any cyanide from their bodies. This was followed by feeding Group 1 with Cajanus cajan prepared feed while Group 2 were fed with commercial feed only, for 72 hours. After 72 hours, the animals in each group were anaesthestized with chloroform and blood collected by cardiac puncture using a syringe. The blood sample from each animal was divided into two 
and dispensed into a plain clean container and an EDTA-containing bottle respectively. The blood in the plain container was allowed to clot and serum separated by centrifuging at $600 \mathrm{x} g$ for 15 minutes and the serum removed by means of pasture pipette. The serum was used for the liver function parameters and cyanide content. The EDTA anti-coagulated blood was used for the determination of haemoglobin concentration. After blood collection, the animals were each carefully dissected and urine samples collected from the bladder using a syringe and stored in a screencapped bottle and kept in the refrigerator until required for analysis.

\section{Determination of antinutrients in the raw seeds}

Tannins, saponins and cyanogenic glycosides contents were determined by the methods of Harborne (1973) and Trease and Evans (1989). Oxalates were determined according to the method of Oke (1969). Phytic acid was determined by the method of Major et al. (1990) and Trypsin inhibitor was determined using the method of Kakade et al. (1979).

\section{Determination of cyanide contents}

Three grammes of each of the commercial feeds, Cajanus cajan prepared feed and raw ground flour of Cajanus cajan seeds were extracted with $15 \mathrm{ml}$ of $0.1 \mathrm{M}$ orthophosphoric acid. The extract was then placed in a tight closed vessel in a refrigerator until required for analysis. The cyanide contents in the various extracts were determined by the procedure based on the spectrophotometeric method of Esser et al. (1993). This analysis was carried at the Research Unit, Department of Biochemistry, Michael Okpara University of Agriculture Umudike, Umuahia.
Determination of concentrations of blood parameters and assay of enzyme activities

The activities of alanine amino transferase (ALT), aspartate amino transferase (AST) and alkaline phosphatase (ALP) were assayed using standard methods as described by Balisteri and Shaw (1987). The concentrations of total protein, bilirubin, creatinine and inorganic phosphate $(\mathrm{Pi})$ were determined using a chemistry analyzer (Cibacorning 550 express plus, USA). The haemoglobin concentration was estimated using the cyanmethaemoglobin method as described by Dacie and Lewis (1994).

\section{Determination of total cyanide contents in serum and urine samples}

The total cyanide contents in the samples were estimated using the spectrophotometeric method for total cyanide in urine and serum as described by Esser et al. (1993)

\section{Statistical analysis}

Data obtained were expressed as means \pm standard deviation and analyzed using Student's ' $t$ ' test and Analysis of Varaince (ANOVA). Values for $\mathrm{P} \leq 0.05$ were taken to be statistically significant (Parker, 1979).

\section{RESULTS}

The results obtained in this study are presented in Tables 1 to 4 . The seed of the brownish-red variety of Cajanus cajan seeds contain high concentrations of cyanogenic glycosides $39.30 \pm 1.30$, phytate $11.57 \pm 1.20$, oxalates $28.58 \pm 1.03$, tannins $0.10 \pm 0.01$, Saponins $5.10+0.20$ in $\mathrm{mg} / 100 \mathrm{~g}$ dry weight and trypsin inhibitor $3.80 \pm 0.10 \mathrm{Tiu} / 100 \mathrm{~g}$ dry weight respectively with cyanogenic glycosides, oxalates and phytate in substantial concentrations (Table 1).

Table 2 shows the cyanide contents of raw Cajanus cajan seed, Cajanus cajan formulated feed and commercial feed. The 
table revealed that Cajanus cajan flour had the highest cyanogenic glycoside content followed by the commercial feed which indicated that commercial feeds contain substantial quantity of cyanogenic glycosides. Table 3 revealed the extent to which the various antinutrients in the Cajanus cajan formulated feed and the commercial feed affected the biochemical parameters analyzed in rabbits. There were reduction in the activities of alanine amino transferase (ALT), aspartate amino transferase (AST) and alkaline phosphatase (ALP) in the group of rabbits fed with commercial feed when compared to those fed with Cajanus cajan formulated feed. There were no significant difference $(p \leq 0.05)$ in the concentrations of total protein, bilirubin, creatinine, inorganic phosphate and haemoglobin in both the test and control rabbits. Table 4 revealed that there was elevated total cyanide contents in the

Table 1: Antinutrient compositions of Cajanus cajan seed extract.

\begin{tabular}{lc}
\hline Antinutrients & $\begin{array}{c}\text { Compositions in seed } \\
\text { extract } \pm \text { S.D* }\end{array}$ \\
\hline Tannins (mg/100gDW) & $0.10 \pm 0.01$ \\
Saponins (mg/100gDW) & $5.10 \pm 0.20$ \\
Trypsin Inhibitor (Tiu/100gDW) & $3.80 \pm 0.10$ \\
Cyanogenic glycosides $(\mathrm{mg} / 100 \mathrm{gDW})$ & $39.3 \pm 1.30$ \\
Oxalates (mg/100gDW) & $28.58 \pm 1.02$ \\
Phytic acid (mg/100gDW) & $11.57 \pm 1.20$ \\
\hline
\end{tabular}

$*$ Values are means of three determinations \pm S.D. DW $=$ Dry Weight

Table 2: Cyanide contents of raw Cajanus cajan seed, Cajanus cajan formulated feed and commercial feed.

\begin{tabular}{lc}
\hline Feeds & Cyanide contents \pm S.D $(\mathbf{m g} / \mathbf{k g})$ \\
\hline Cajanus cajan flour & $39.5 \pm 2.30$ \\
Cajanus cajan formulated feed & $18.32 \pm 3.07$ \\
Commercial feed & $26.50 \pm 2.04$ \\
\hline
\end{tabular}

*Values are means of three determinations \pm S.D.

Table 3: Effects of Cajanus cajan formulated feed on the biochemical parameters of New Zealand rabbits.

\begin{tabular}{|c|c|c|c|c|c|c|c|c|}
\hline Group & $\begin{array}{c}\text { Total } \\
\text { Protein } \\
\text { (g/l) }\end{array}$ & $\begin{array}{c}\text { Total } \\
\text { Bilirubin } \\
(\mu \mathrm{mol} / \mathrm{l})\end{array}$ & $\begin{array}{l}\text { Creatinine } \\
\text { (mg/dl) }\end{array}$ & $\begin{array}{c}\text { Inorganic } \\
\text { phosphate } \\
(\text { pi) } \\
(\mathrm{mg} / \mathrm{dl})\end{array}$ & $\begin{array}{l}\text { Haemoglobin } \\
(\mathrm{Hb})(\mathrm{g} / \mathrm{l})\end{array}$ & $\begin{array}{c}\text { Alanine } \\
\text { amino } \\
\text { transferase } \\
(\text { ALT })(\text { IU/I })\end{array}$ & $\begin{array}{c}\text { Aspartate } \\
\text { amino } \\
\text { transferase } \\
(\text { ALT) }(\text { IU/I) }\end{array}$ & $\begin{array}{c}\text { Alkaline } \\
\text { phosphatase } \\
\text { (ALP) } \\
\text { (IU/I) }\end{array}$ \\
\hline 1 & $6.19 \pm 0.22$ & $21.20 \pm 0.01$ & $0.94 \pm 0.01$ & $3.87 \pm 0.12$ & $8.02 \pm 0.12$ & $7.89 \pm 0.22$ & $5.16 \pm 0.30$ & $2.80 \pm 0.10$ \\
\hline 2 & $6.83 \pm 0.20$ & $01.27 \pm 0.13$ & $30.93 \pm 0.02$ & $3.60 \pm 0.03$ & $8.13 \pm 0.14$ & $2.73 \pm 0.03$ & $2.67 \pm 0.13$ & $1.27 \pm 0.20$ \\
\hline t-value & 0.03 & 0.85 & 0.89 & 0.20 & 0.76 & 46.48 & 6.89 & 8.65 \\
\hline $\mathrm{P}$ & $>0.05$ & $>0.05$ & $>0.05$ & $>0.05$ & $>0.05$ & $<0.05$ & $<0.05$ & $<0.05$ \\
\hline
\end{tabular}


Table 4: total cyanide contents in the serum and urine samples of New Zealand rabbits.

\begin{tabular}{llc}
\hline Samples & \multicolumn{2}{c}{ Cyanide Contents $(\mathbf{m g} / \mathbf{l})^{*}$} \\
\hline \multirow{2}{*}{ Urine } & Group 2 & Group 1 \\
Serum & $25.5 \pm 1.05$ & $3.5 \pm 0.10$ \\
& $27.5 \pm 1.50$ & $5.0 \pm 0.10$ \\
\hline
\end{tabular}

$*$ Values and means of three determinations \pm S.D

serum and urine samples of rabbits fed with commercial feed when compared to those fed with Cajanus cajan formulated feed.

\section{DISCUSSION}

Cyanogenic glycosides, oxalates and trypsin inhibitor are toxic at high concentration in the blood, although, processing usually reduces their concentrations. The presence and concentration of phytate, typsin inhibitor and cyanogenic glycosides should sound a note of caution in the frequent consumption of Cajanus cajan pulse as dietary protein. Trypsin inhibitor affects protein digestibility adversely.

Phytate is not easily destroyed by processing temperature. This is attributable to phytate having twelve replaceable hydrogen atoms and therefore could form insoluble salts with many metals $\mathrm{cu}^{2+}, \mathrm{Zn}^{2+}, \mathrm{Co}^{2+}, \mathrm{Fe}^{2+}, \mathrm{Cd}^{+}$ and $\mathrm{Ca}^{2+}$ (Jack et al., 1985; McCane and Woddowson, 1953).

Cyanogenic glycosides are precursors of hydrogen cyanide, a well known natural toxicant in foods. The high concentration of this toxicant serves a note of caution due to its toxicity in the blood.

The results in Table 3 reveal the extent to which the biochemical parameters measured were affected by the high concentration of cyanogens in the Cajanus cajan prepared feed. The fact that the mean value concentrations for total protein, bilirubin, creatinine, inorganic phosphate and haemoglobin did not differ significantly between the test and control groups would mean that the prepared Cajanus cajan feed did not affect these parameters. The elevation of ALT and AST in the test group than the control group would be associated with cell necrosis of some tissues in the body such as myocardial infarction, liver disorder and toxic jaundice (Singh, 2004). This is because pathology involving tissues such as liver, cardiac and skeletal muscles allow for the leakage of these enzymes into the blood stream.

Alkaline phosphatase (ALP), another liver enzyme was lower in concentration in the serum of rabbits fed with commercial feed than in the test. Decrease in ALP activity is a rare phenomenon in metabolism. However, it has been observed in severely malnourished children and in hypophosphatasia - an uncommon inborn error of metabolism (Henry, 1984).

The high level of cyanide in the urine and serum of test group indicated exposure to cyanide resulting from ingestion of Cajanus cajan seeds (Table 4). It is interesting to note that reasonable amount of cyanide were found in the urine and serum of rabbits from the control group. This is expected, since the commercial feed given to the control group was found to contain substantial level of cyanide higher than that found in Cajanus cajan formulated feed (Table 2). The level of cyanide in both the commercial and Cajanus cajan prepared feeds agrees with earlier report 
of Montgomery (1965) that many plant food stuffs in common use particularly in the tropics contain cyanide in the form of cyanogenic glycosides.

According to Oke (1980), the level of cyanide is considered to be less toxic if it is less than $50 \mathrm{ppm}$, moderately toxic between 50 to $100 \mathrm{ppm}$ and highly toxic above 100 ppm. Based on this, the level of cyanide contained in the serum and urine of rabbits fed with prepared Cajanus cajan feed flour can be said to be less toxic. Since the cyanogenic glycoside of Cajanus cajan was found to be $39.30 \pm 1.30 \mathrm{mg} / 100 \mathrm{~g}$ DW. However, the reverse may the case in condition of economic stress considering that cassava and its products, another cyanogenic plant is the staple food for most Nigerians.

\section{Conclusion}

The study revealed that consumption of Cajanus cajan seed made pulses would not result to cyanide toxicity in animals and humans. It is recommended that more work should be done to evaluate the effect of processing on the antinutritional factors present in the seed in order to exploit the nutritional potential of this under utilized seed, especially in the present economic hardship.

\section{REFERENCES}

Allen ON, Allen CK 1981. The Leguminosa: A Source Book of Characteristic, Uses and Nodulation. Macmillan Publishers Ltd: London; 45 - 58.

Aremu CY. 1989. Quantitative estimation of dietary contributions of phytate, oxalate and hydrocyanate by $\mathrm{Six}$ popular Nigerian foodstuffs. Nig. J. Nutri Sci., 10: $79-84$.

Balistreri WR, Shaw LM. 1987. Liver function. In Fundamentals of Clinical Chemistry $\left(3^{\text {rd }}\right.$ edn), Tietz NW (ed). W.B.
Saunders Company: Philadephia; 729_ 761.

Dacie JV, Lewis SM. 1994. Practical Haematology ( $8^{\text {th }}$ edn). Longman Group Ltd: Hong Kang; 49 - 82.

Elegbede JA. 1998. Legumes. In Nutritional Quality of Plant Foods, Osagie AU, Eka OU (eds). Post-harvest Research Unit, University of Benin: Benin, Nigeria; 53 85.

Ekpeche OL 1973. Endemic Goiter and High Cassava Diets in Eastern Nigeria. IDRC136D; $45-60$.

Esser AJA, Bosveld M, VanderGift RM, Voragen AGJ. 1993. Studies on the quantification of specific cyanogens in cassava products and introduction of a new chromogens. J. Sci. Food Agric., 63(3): $287-296$.

Henry JB. 1984. Clinical Diagnoses and Management by Laboratory Methods (17 $7^{\text {th }}$ edn). WB Saunders Company; 241 250.

Harborne JB. 1973. Phytochemical Methods. A Guide to Modern Techniques of Plant Analyses. Chapman and Hall: New York; $16-19$.

Jack GA, Rambeck WA, Kollmer WE. 1985. Retention of cadmium in organs of rats after single dose of labelled cadmium -3phytate. Boil Trace Elem. Res., 6: 69 74.

Kakade ML, Bakis JJ, McGec JE, Puski GC. 1979. Determination of trypsin inhibition activity of soy products: A collaboration of analysis of an improved procedure. Ameri. Assoc. Cereal Chem., 51: 376383.

McCane RA, Woddowson EM. 1953. Phytin in human nutrition. Biochem. J., 29: 2694-2699.

Montgomery RD. 1965. The medical significance of cyanogen in plant food stuff. Amer. J. Clini. Nutri., 17: 103-113. 
Obizoba IC. 1998. Fermented foods. In Nutritional Quality of Plant Foods, Osagie AU, Eka OU (eds). Post-harvest Research Unit, University of Benin: Benin, Nigeria; 160-198.

Obizoba IC. 1991. Effect of sprouting on the nitrogenous constituent and mineral composition of pigeon pea (Cajanus cajan) seeds. Human Nutrition, 14: 2126.

Oke OL. 1980. Toxicity of cyanogenic glycosides. Food Chem., 6: 97 - 109.

Osagie AU. 1998. Antinutritional factors. In Nutritional Quality of Plant Foods, Osagie AU, Eka OU (eds). Post-harvest Research Unit, University of Benin: Benin, Nigeria; 221 - 244.

Onigbinde OA, Akinyele LO. 1983. Oligosaccharide content of liverly varieties of cowpeas in Nigeria. J. Food Sci., 48: 1250 - 1255.
Okolie NP, Ugochukwu EN. 1988. Cyanide contents of some Nigeria legumes and the effect of simple processing. Food Chemistry, 32: 209 - 210.

Parker RE. 1979. Introductory Statistics for Biology ( $2^{\text {nd }}$ edn.). Arnold Publishers Ltd London. Chapman and Hall: New York; 122-123.

Singh SP. 2004. Practical Manual of Biochemistry $\left(5^{\text {th }}\right.$ edn). CBS Publisher and Distributors: New Delhi, India; 201210.

Trease GE, Evans WC. 1989. Textbook of Pharmacognosy (12 $2^{\text {th }}$ edn). Balliese Tindall and Company Publisher: London; $343-388$. 